\title{
Effect of neutrophil elastase and its inhibitor EPI-hNE4 on transepithelial sodium transport across normal and cystic fibrosis human nasal epithelial cells
}

Virginie Prulière-Escabasse ${ }^{1,2,3^{*}}$, Christine Clerici ${ }^{4,5,6}$, Grégoire Vuagniaux ${ }^{7}$, Andre Coste ${ }^{1,2,3}$, Estelle Escudier ${ }^{8,9}$, Carole Planès ${ }^{10,11}$

\begin{abstract}
Background: Hyperactivity of the epithelial sodium $\left(\mathrm{Na}^{+}\right)$channel $(\mathrm{ENaC})$ and increased $\mathrm{Na}^{+}$absorption by airway epithelial cells leading to airway surface liquid dehydration and impaired mucociliary clearance are thought to play an important role in the pathogenesis of cystic fibrosis (CF) pulmonary disease. In airway epithelial cells, ENaC is constitutively activated by endogenous trypsin-like serine proteases such as Channel-Activating Proteases (CAPs). It was recently reported that $\mathrm{ENaC}$ activity could also be stimulated by apical treatment with human neutrophil elastase (hNE) in a human airway epithelial cell line, suggesting that hNE inhibition could represent a novel therapeutic approach for CF lung disease. However, whether hNE can also activate $\mathrm{Na}^{+}$reabsorption in primary human nasal epithelial cells (HNEC) from control or CF patients is currently unknown.
\end{abstract}

Methods: We evaluated by short-circuit current $\left(I_{s c}\right)$ measurements the effects of hNE and EPI-hNE4, a specific hNE inhibitor, on ENaC activity in primary cultures of HNEC obtained from control (9) and CF (4) patients.

Results: Neither hNE nor EPI-hNE4 treatments did modify $I_{s c}$ in control and CF HNEC. Incubation with aprotinin, a Kunitz-type serine protease inhibitor that blocks the activity of endogenous CAPs, decreased $I_{\text {sc }}$ by $27.6 \%$ and $54 \%$ in control and CF HNEC, respectively. In control and CF HNEC pretreated with aprotinin, hNE did significantly stimulate $I_{\text {sc }}$ an effect which was blocked by EPI-hNE4.

Conclusions: These results indicate that hNE does activate $\mathrm{ENaC}$ and transepithelial $\mathrm{Na}^{+}$transport in both normal and CF HNEC, on condition that the activity of endogenous CAPs is first inhibited. The potent inhibitory effect of EPI-hNE4 on hNE-mediated ENaC activation observed in our experiments highlights that the use of EPI-hNE4 could be of interest to reduce $\mathrm{ENaC}$ hyperactivity in CF airways.

\section{Introduction}

Abnormalities in cyclic AMP-dependent chloride secretion and excessive sodium $\left(\mathrm{Na}^{+}\right)$reuptake by airway epithelial cells related to cystic fibrosis transmembrane conductance regulator (CFTR) deficiency are thought to alter fluid homeostasis at the airway surface liquid leading to dehydration, impaired mucociliary clearance, and infection [1]. Activation of CFTR $\mathrm{Cl}^{-}$channel is known to inhibit epithelial $\mathrm{Na}^{+}$channel $(\mathrm{ENaC})$ in normal

\footnotetext{
* Correspondence: virginie.escabasse@chicreteil.fr

'INSERM, U 955, Créteil, F-94000, France

Full list of author information is available at the end of the article
}

native airway epithelial cells. In CF airways, mutation of CFTR leads to increased $\mathrm{ENaC}$ activity with increased transepithelial $\mathrm{Na}^{+}$and water reabsorption [2-5]. Indeed, it has been shown that overexpression of the $\beta$-ENaC subunit in mouse airways increases $\mathrm{Na}^{+}$reabsorption, decreases mucociliary and bacterial clearance and leads to airway inflammation and obstruction, and to a cystic fibrosis-like disease [6]. Therefore, inhibition of $\mathrm{ENaC}$ activity in the airways has been proposed for treatment of CF pulmonary disease.

Despite its physiological importance in lung fluid homeostasis, the tissue-specific regulation of $\mathrm{ENaC}$ in airways is

\section{C) Biomed Central}


still poorly understood. Most studies have focused on the systemic regulation of $\mathrm{ENaC}$ by hormones [7], but the role of extracellular luminal factors present in the immediate vicinity of the channel has been scarcely investigated. In recent years, the concept of an autocrine regulation of $\mathrm{ENaC}$ by epithelium derived extracellular serine proteases has emerged from several observations [8,9]. In 1997, using functional complementation assays to detect increases in $\mathrm{ENaC}$ activity in the Хenopus kidney A6 renal cell line, Vallet et al (10) cloned a trypsin-like serine protease, the channel-activating protease 1 (CAP1). This glycosylphophatidylinositol-anchored protease increased amiloride-sensitive $\mathrm{Na}^{+}$current when coexpessed $\mathrm{ENaC}$ in Xenopus oocytes $[10,11]$. ENaC activation was fully prevented by extracellular addition of the serine protease inhibitor aprotinin and mimicked by external tryspsin. Mammalian homologs of Xenopus CAP1, such as mouse mCAP1 or human and rat prostasin, were also shown to activate $\mathrm{ENaC}$ in the Xenopus oocytes expression system [12-15]. More recently, additional transmembrane serine proteases activating $\mathrm{ENaC}$ have been identified in mammals, including channel-activating protease 2 (CAP2) and channel-activating protease 3 (CAP3) cloned from the mpkCCD $D_{\mathrm{d} 4}$ mouse kidney cell line [14], TMPRSS3 from human inner ear [16], or TMSP-1 from rat kidney [17]. The precise mechanism for protease-mediated activation of $\mathrm{ENaC}$ has not been fully elucidated, but it likely involves proteolytic cleavage of $\alpha$ - and $\gamma$ - ENaC subunits $[9,16]$. Studies in Xenopus oocytes $[13,14,17]$ or transfected mammalian cells [18] have demonstrated that trypsin-like serine proteases increase $\mathrm{Na}^{+}$transport by activating a population of near-silent channels rather than by promoting plasma membrane insertion of new channels. In mammals, the channel-activating proteases (CAP1,-2 and 3) are coexpressed with $\mathrm{ENaC}$ in epithelial tissues transporting $\mathrm{Na}^{+}$like renal collecting duct, lung, and colon $[12,19,20]$. Concerning the lung, we have recently shown that CAP1 is an important regulator of transepithelial alveolar $\mathrm{Na}^{+}$ transport in vitro and in vivo, and of lung fluid homeostasis in the mouse [21,22]. Indeed, it was reported that $\mathrm{Na}^{+}$ absorption across bronchial or nasal epithelial cells was regulated in vitro by endogenous aprotinin-sensitive serine protease(s) $[15,23]$. Prostasin, the human homolog of CAP1 expressed in proximal airways, was proposed as a likely candidate for this regulation [15,24].

Caldwell et al recently reported that $\mathrm{ENaC}$ activity and transepithelial $\mathrm{Na}^{+}$transport could be increased by apical treatment with human neutrophil elastase (hNE) in a human airway epithelial cell line [18]. However, it seems that this human airway epithelial cell line did not have any endogenous CAP activity inasmuch as treatment with aprotinin, an inhibitor of endogenous CAPs, did not modify transepithelial $\mathrm{Na}^{+}$transport. Whether hNE can also activate $\mathrm{ENaC}$ and $\mathrm{Na}^{+}$reabsorption in primary bronchial cells known to endogenously express CAPs is currently unknown. This is an important point inasmuch as hNE can be found at high concentration in airway surface liquid from CF patients, due to neutrophil activation. If hNE does activate $\mathrm{ENaC}$ and transepithelial $\mathrm{Na}^{+}$transport in CF airways, the use of hNE inhibitors could have a therapeutic interest for treatment of CF lung disease.

Our working hypotheses were (i) that hNE would stimulate $\mathrm{ENaC}$ and transepithelial $\mathrm{Na}^{+}$transport in primary human airway epithelial cells, and (ii) that EPIhNE4, a specific and potent inhibitor of hNE [22], could block this stimulation. The objectives of the study were therefore to test the effects of hNE and EPI-hNE4 on $\mathrm{ENaC}$ activity and transepithelial $\mathrm{Na}^{+}$transport in vitro in primary cultures of human nasal epithelial cells from control and CF patients.

\section{Experimental Procedures}

\section{Primary cultures of human nasal epithelial cells (HNEC)}

Nasal polyps (NP) were obtained from non CF $(n=9)$ or $\mathrm{CF}(\Delta \mathrm{F} 508 / \Delta \mathrm{F} 508, \mathrm{n}=4)$ patients requiring surgery for their nasal polyposis as previously described [25]. The diagnosis of nasal polyposis was established on the basis of clinical history, endoscopic findings and computed tomography results. This protocol was approved by the Institutional Review Board and ethics committee of our institution (CPP, Hôpital Henri Mondor), and informed consent was obtained from all patients. NP samples were immediately placed in DMEM/F12 supplemented with antibiotics $(100 \mathrm{U} / \mathrm{ml}$ of penicillin, 100 $\mathrm{mg} / \mathrm{ml}$ of streptomycin, $2.5 \mu \mathrm{g} / \mathrm{ml}$ of amphotericin B and $100 \mathrm{mg} / \mathrm{ml}$ of gentamicin) and transported to the laboratory for cell isolation. Briefly, NP samples were rinsed in phosphate-buffered saline (PBS) with dithiothreitol $(5 \mathrm{nM})$ and antibiotics $(100 \mathrm{U} / \mathrm{ml}$ of penicillin, $100 \mathrm{mg} / \mathrm{ml}$ of streptomycin, $2.5 \mu \mathrm{g} / \mathrm{mL}$ of amphotericin $B$ and $100 \mathrm{mg} / \mathrm{ml}$ of gentamicin) and then placed overnight at $4^{\circ} \mathrm{C}$ in a PBS-antibiotics solution containing $0.1 \%$ pronase. The samples were incubated in DMEM/ F12 with $5 \%$ fetal calf serum (FCS) before centrifugation (1,500 rpm, 7 minutes). Cell pellets were then suspended in $0.25 \%$ trypsin-ethylenediamine tetra-acetic acid (EDTA) solution for 3 minutes and incubated in DMEM/F12-antibiotics with $10 \%$ FCS. Finally, HNEC were plated on permeable polycarbonate supports (Snapwell ${ }^{\circ}$, Costar, Cambridge, USA) $\left(1 \times 10^{6} \mathrm{cells} / \mathrm{cm}^{2}\right)$ for short-circuit measurements. All inserts had a diameter of $12-\mathrm{mm}$ and were coated with type IV collagen. $\mathrm{HNEC}$ were incubated at $37^{\circ} \mathrm{C}$ in $5 \% \mathrm{CO}_{2}$. For the first 24 hours, HNEC were incubated with $1 \mathrm{ml}$ of DMEM/ F12-antibiotics with $2 \%$ Ultroser G outside the insert and DMEM/F12-antibiotics with 10\% FCS inside the insert. After 24 hours, medium was removed inside the 
inserts in order to place the cells at an air-liquid interface, and medium outside the inserts was then changed daily. Transepithelial resistance and transepithelial potential difference were measured every three days using a microvoltmeter (World Precision Instruments, Astonbury, UK). Experiments were performed 2-3 weeks after isolation.

\section{Electrophysiological studies}

Measurements of short-circuit current $\left(I_{\mathrm{sc}}\right)$, transepithelial potential difference, and transepithelial resistance were performed in Snapwell inserts mounted in vertical diffusion chambers and bathed with Ringer solution $(\mathrm{pH}$ 7.4) continuously bubbled with $5 \% \mathrm{CO}_{2}-95 \%$ air at $37^{\circ} \mathrm{C}$. The apical and basolateral chambers were filled with (in $\mathrm{mM}$ ): $137 \mathrm{NaCl}, 5.6 \mathrm{KCl}, 1.9 \mathrm{CaCl}_{2}, 1.2 \mathrm{MgCl}_{2}, 5.9$ $\mathrm{CH}_{3} \mathrm{COONa}, 1.3 \mathrm{NaH}_{2} \mathrm{PO}_{4}, 10$ HEPES and 10 glucose. $\mathrm{PD}$ was short-circuited to $0 \mathrm{mV}$ with a voltage clamp (World Precision Instruments, Astonbury, UK) connected to the apical and basolateral chambers via Ag$\mathrm{AgCl}$ electrodes and agar bridges in order to measure $I_{\mathrm{sc}}$ by Ohm's law. Isc was allowed to stabilize, before adding the drugs.

\section{Treatment of HNEC cultures}

Human neutrophil elastase (Serva Electrophoresis; final concentration: 10 or $33 \mu \mathrm{g} / \mathrm{ml}$, equivalent to 0.2 and $0.66 \mathrm{U} / \mathrm{ml}$, respectively), EPI-hNE4 (developed by Dyax Corp., Cambridge, MA; final concentration: 10 or $33 \mu \mathrm{g} /$ $\mathrm{ml}$ ), trypsin (Sigma; final concentration: $100 \mu \mathrm{g} / \mathrm{ml}$, equivalent to $1,000 \mathrm{BAEE}$ units $/ \mathrm{ml}$ ) or vehicle were added after establishing a stable $I_{\text {sc }}$ into the apical compartment and $I_{\mathrm{sc}}$ was monitored for 30 to $60 \mathrm{~min}$ before apical addition of $10 \mu \mathrm{M}$ amiloride, a specific inhibitor of $\mathrm{ENaC}$. Amiloride-sensitive $I_{\mathrm{sc}}$ was determined as the difference in current with and without amiloride (10 $\mu \mathrm{M})$. In the second part of the study, the serine protease inhibitor aprotinin (Sigma; final concentration: $50 \mu \mathrm{g} / \mathrm{ml}$, equivalent to 0.25 Trypsin Inhibitor Unit (TIU)/ml) was added into the apical compartment and $I_{\text {sc }}$ was monitored for 75 to $90 \mathrm{~min}$ before apical addition of hNE alone (final concentration: $33 \mu \mathrm{g} / \mathrm{ml}$ ), or of EPI-hNE4 (final concentration: $33 \mu \mathrm{g} / \mathrm{ml}$ ) followed by hNE (final concentration: $33 \mu \mathrm{g} / \mathrm{ml})$.

\section{Statistical analysis}

Data are expressed as\% of baseline value (before addition of drug) or as changes in $I_{\mathrm{sc}}\left(\Delta I_{\mathrm{sc}}\right.$, representing the difference between the value of $I_{\mathrm{sc}}$ at the end of exposure to drug or vehicle and the baseline $I_{\mathrm{sc}}$ at the moment of drug or vehicle addition), and are presented as means \pm SE of 4-10 filters per condition. Statistics were performed on $\Delta I_{\mathrm{sc}}$ values. Treatment groups were compared by one-way variance analyses and, when allowed by the $\mathrm{F}$ value, results were compared by the modified least significant difference (Statview Software). $\mathrm{P}<0.05$ was considered significant.

\section{Results}

Treatment of control and CF HNEC with hNE

HNEC cultures were derived from nine non-CF and four CF (homozygous $\Delta F 508 / \Delta$ F508) subjects. Thirtyfive individual normal HNEC and nineteen CF HNEC filters displayed high transepithelial resistance and stable $I_{\mathrm{sc}}$ values, and could be used in this study. Electrophysiological properties of cultured HNEC from non CF and CF patients are presented in Table 1.

We first tested the effect of hNE on transepithelial $\mathrm{Na}^{+}$ transport in control and CF HNEC monolayers. As shown in Figure 1, increasing concentrations of hNE (final concentration in the apical bath: 10 and $33 \mu \mathrm{g} / \mathrm{ml}$ ) did not induce any noticeable change in $I_{\mathrm{sc}}$ value in control HNEC. Indeed, $\Delta I_{\text {sc }}$ (representing the difference between the value of $I_{\mathrm{sc}}$ at the end of exposure to drug or vehicle and the baseline) was not significantly different in cells treated with hNE as compared with vehicle (Figure 2A) $(\mathrm{n}=4-6)$. Treatment with excess trypsin (final concentration: $100 \mu \mathrm{g} / \mathrm{ml}$ ), a serine protease known to activate $\mathrm{ENaC}$ and $\mathrm{Na}^{+}$transport in lung epithelial cells, also did not modify $I_{\mathrm{sc}}$ value in control HNEC (Figure 2A). Similar results were obtained in CF HNEC since neither hNE (final concentration in the apical bath: 10 and $33 \mu \mathrm{g} / \mathrm{ml}$ ) nor trypsin (final concentration: $100 \mu \mathrm{g} / \mathrm{ml}$ ) did significantly modify $\Delta I_{\mathrm{sc}}$ as compared with vehicle $(\mathrm{n}=3-4)$ (Figure 1 and $2 \mathrm{~B}$ ). These data show that, in cultured HNEC, ENaC-mediated transepithelial $\mathrm{Na}^{+}$transport could not be stimulated by treatment with exogenous serine proteases such as hNE and trypsin.

\section{Treatment of control and CF HNEC with EPI-hNE4}

We next studied the effect of the hNE inhibitor EPIhNE4 on control and CF HNEC to test whether this compound was able to modify transepithelial $\mathrm{Na}^{+}$

Table 1 Electrophysiological properties of cultured HNEC from normal and CF patients

\begin{tabular}{ccc}
\hline & Control HNEC & CF HNEC \\
\hline PD $(\mathrm{mV})$ & $36.8 \pm 2.18$ & $57 \pm 2.23^{* * *}$ \\
\hline$R_{\mathrm{te}}\left(\Omega . \mathrm{cm}^{2}\right)$ & $969 \pm 67.7$ & $953 \pm 48.1$ \\
\hline$I_{\mathrm{sc}}\left(\mu \mathrm{A} / \mathrm{cm}^{2}\right)$ & $41.8 \pm 3.42$ & $60.7 \pm 3.19^{* *}$ \\
\hline
\end{tabular}

Human nasal epithelial cells (HNEC) from control (non CF) and CF patients were grown for 14 to 21 days on semi-permeable transwell filters until transepithelial resistance developed. Transwell filters were mounted in Ussing chamber for measurement of voltage (PD) and short-circuit current $\left(I_{\mathrm{sc}}\right)$. Transepithelial resistance $\left(R_{\mathrm{te}}\right)$ was calculated with Ohm's law from $I_{\mathrm{sc}}$ and PD. Results represent means \pm SE of 25 individual filters from 9 separate cultures of non CF HNEC, and of 9 individual filters from 4 separate cultures of CF HNEC.

$*^{*},{ }^{* *}$ : significantly different from corresponding value in control HNEC group $(P<0.01$ and $P<0.001$, respectively). 


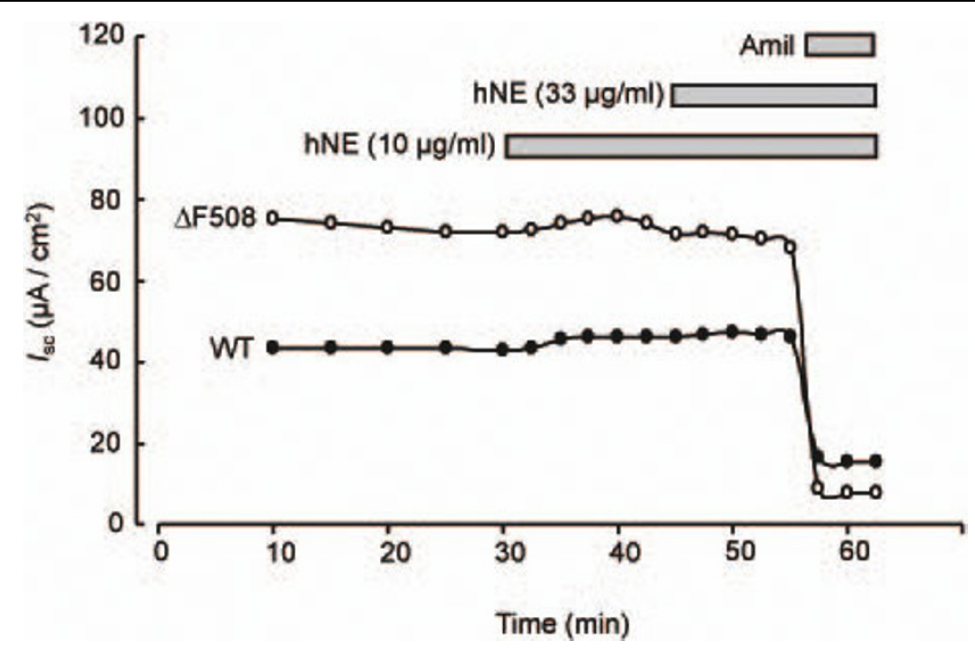

Figure 1 Representative traces of short-circuit current measurements showing the effect of hNE in control and CF HNEC. HNEC from control (WT) or CF patients ( $\triangle F 508$ ) grown on Snapwell filters and mounted in Ussing chamber were exposed apically to hNE (final concentration: 10 and $33 \mu \mathrm{g} / \mathrm{ml}$ ) for 30 minutes before amiloride (final concentration: $10 \mu \mathrm{M}$ ) was added.

transport. Treatment with a high concentration of EPIhNE4 (final concentration: $100 \mu \mathrm{g} / \mathrm{ml}$ ) did not significantly modify $I_{\mathrm{sc}}$ in control HNEC $(\mathrm{n}=5)$ or CF HNEC $(\mathrm{n}=4)$, as compared with vehicle (Table 2$)$.

\section{Effect of hNE and EPI-hNE4 treatment in control and CF HNEC preincubated with aprotinin}

Taken together, the results indicate that neither hNE nor its inhibitor EPI-hNE4 is able to modify ENaC-mediated $\mathrm{Na}^{+}$transport in HNEC. We hypothesized that this lack of effect of hNE was due to the expression in HNEC of endogenous serine proteases known to activate $\mathrm{ENaC}$ in human airway epithelial cells, such as CAPs. To test this hypothesis, cells were pre-incubated with aprotinin (final concentration: $50 \mu \mathrm{g} / \mathrm{ml}$ in the apical bath), a Kunitz-type serine protease inhibitor, before hNE (with or without EPI-hNE4) was added. Aprotinin induced a $27.6 \pm 3.47 \%$ decrease in control HNEC total $I_{\mathrm{sc}}$ that was completely achieved within $90 \mathrm{~min}$ (Figure 3, 4 and Table 3). This decrease was rapidly and completely reversed by apical addition of hNE (final concentration $33 \mu \mathrm{g} / \mathrm{ml}$ ). The stimulatory effect of hNE on $I_{\mathrm{sc}}$ was fully prevented when cells were treated with EPI-hNE4 (final concentration $33 \mu \mathrm{g} / \mathrm{ml}) 5$ minutes before hNE addition $\left(\Delta I_{\mathrm{sc}}:-15.7 \pm\right.$ 3.56 vs $-14.2 \pm 4.70 \mu \mathrm{A} / \mathrm{cm}^{2}$ for aprotinin alone and aprotinin followed by EPI-hNE4 + hNE, respectively; NS).

In CF HNEC, aprotinin decreased total $I_{\mathrm{sc}}$ by $54 \pm$ $8.18 \%$ in CF HNEC (Figure 3, 4 and Table 3). The aprotinin-induced inhibition of $I_{\mathrm{sc}}$ was significantly greater in CF HNEC than in control HNEC (Table 3). Apical addition of hNE significantly increased $I_{\mathrm{sc}}$ in aprotinintreated CF HNEC. HNE-induced stimulation of $I_{\mathrm{sc}}$ tended to be higher in CF HNEC than in control HNEC, although the difference was not significant $(\mathrm{p}=$ 0.06) (Table 3). However, hNE addition did not completely restore $I_{\mathrm{sc}}$ to the baseline value in CF HNEC (Figure 3 and 4). The stimulatory effect of hNE in aprotinintreated CF HNEC was completely blocked by preincubation with EPI-hNE4 $(\mathrm{n}=2)$.

\section{Discussion}

This study was designed to test the effect of hNE and its specific inhibitor EPI-hNE4 on transepithelial $\mathrm{Na}^{+}$transport across cultured normal and CF HNEC. Our results showed that neither hNE nor trypsin treatment did modify $I_{\mathrm{sc}}$ in normal and CF HNEC, suggesting that $\mathrm{ENaC}$ at cell surface was already fully activated by endogenous serine proteases such as epithelial CAPs. Indeed, inhibition of endogenous CAPs with aprotinin induced a sustained decrease in $I_{\mathrm{sc}}$ in both normal and CF HNEC, supporting this hypothesis. Interestingly, apical treatment with exogenous hNE completely and rapidly reversed the aprotinin-induced decrease in $I_{\mathrm{sc}}$ normal and CF cells. EPI-hNE4 by itself did not modify $I_{\mathrm{sc}}$ in normal or CF HNEC, indicating that this compound is a specific inhibitor of hNE and in this way could not inhibit endogenous CAPs. However, EPI-hNE4 completely abolished the stimulatory effect of hNE in cells pretreated with aprotinin in normal and CF patients. Taken together, our results suggest that in some conditions when endogenous CAPs are downregulated, hNE could stimulate $\mathrm{ENaC}$-mediated $\mathrm{Na}^{+}$transport in both normal and CF HNEC, and that EPI-hNE4 could potently block this effect. 

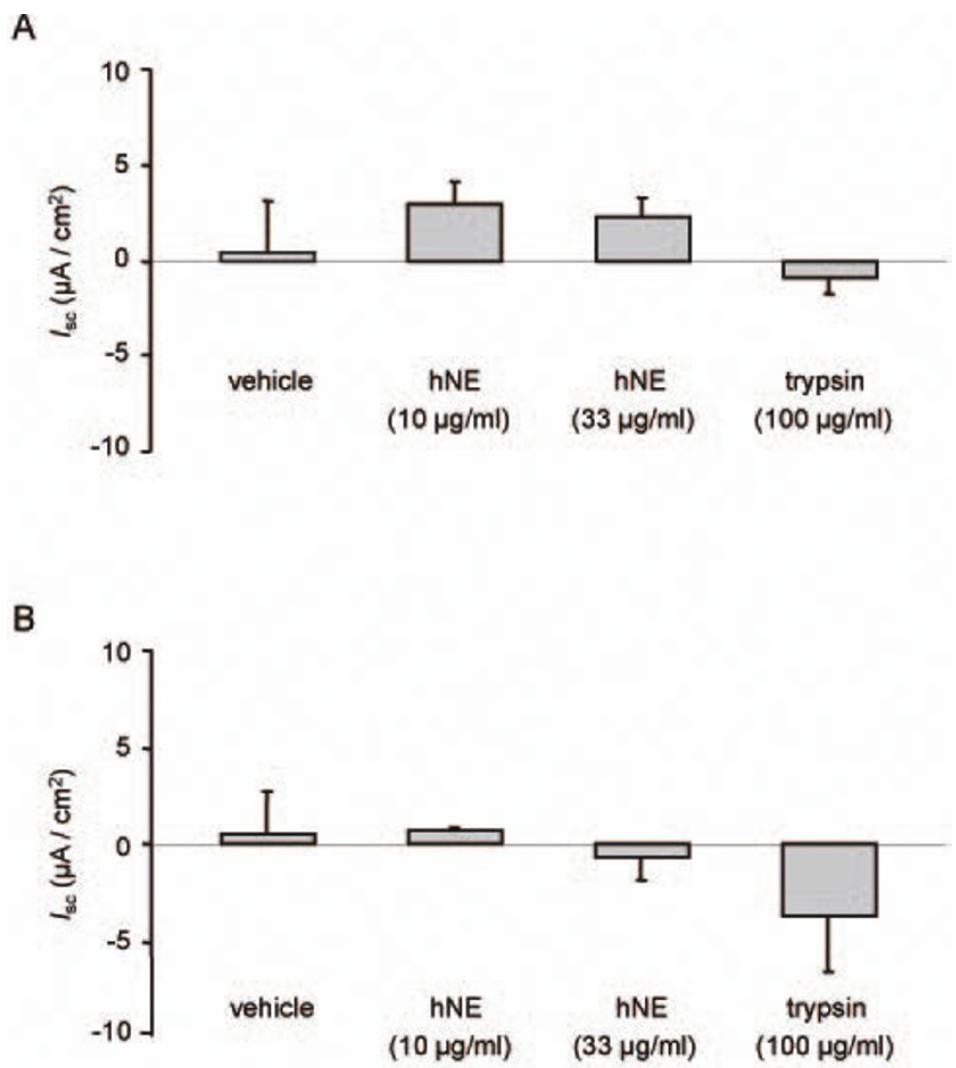

Figure 2 Effect of hNE and trypsin on transepithelial $\mathrm{Na}^{+}$transport across control and CF HNEC. HNEC from control (panel A) or CF ( $\triangle$ F508) patients (panel B) grown on Snapwell filters and mounted in Ussing chamber were exposed apically to hNE, trypsin or vehicle. $\Delta I_{s c}$ was calculated as the difference between the value of short-circuit current $\left(I_{\mathrm{sc}}\right)$ at the end of exposure to drug or vehicle and the baseline $I_{s c}$ at the moment of drug or vehicle addition. Results are expressed in $\mu \mathrm{A} / \mathrm{cm}^{2}$ and represent means \pm SE of five to seven filters for each condition: vehicle, hNE $(10 \mu \mathrm{g} / \mathrm{ml})$, hNE $(33 \mu \mathrm{g} / \mathrm{ml})$, and trypsin $(100 \mu \mathrm{g} / \mathrm{ml})$.

Mucus clearance is a major component of the lung innate defence mechanism. The efficiency of mucus clearance is partly dependent on the volume of airway surface liquid (ASL) on airway surfaces. The ASL is comprised of a periciliary liquid layer, which lubricates the cell surface, and a mucus layer, which traps airborne particules and pathogens. Cystic fibrosis airways exhibit $\mathrm{Na}^{+}$hyperabsorption and $\mathrm{Cl}^{-}$hyposecretion, which leads to ASL volume depletion, mucus stasis and mucus plugging, which promote persistent bacterial infections [1]. Recent findings yielded novel insights into the role of $\mathrm{ENaC}$ hyperactivity in the in vivo pathogenesis of CF. Mall et al have demonstrated in a mouse model, that overexpression of the $\beta$-subunit of $\mathrm{ENaC}$ was sufficient to increase airway $\mathrm{Na}^{+}$absorption in vivo [6]. In this animal model, elevated airway $\mathrm{Na}^{+}$absorption caused airway surface liquid depletion, reduced mucus clearance, and deficient mucus clearance produced spontaneous lung disease sharing key features with CF $[6,26]$. Because $\mathrm{ENaC}$ hyperactivity in the airways is thought to play a key role in the pathogenesis of $\mathrm{CF}$, decreasing ENaC-mediated $\mathrm{Na}^{+}$transport represents a therapeutic target to control ASL volume in CF airways.

It has been recently shown that $\mathrm{ENaC}$ channels expressed at the cell surface can be activated in vitro and in vivo by various trypsin-like serine proteases

Table 2 Effect of the hNE inhibitor EPI-hNE4 on $\Delta I_{s c}$ in HNEC from control and CF patients

\begin{tabular}{ccccc}
\hline & \multicolumn{3}{c}{ Control HNEC } & \multicolumn{2}{c}{ CF HNEC } \\
\cline { 2 - 5 } & Vehicle & EPI-hNE4 (100 $\boldsymbol{\mu g} / \mathbf{m l})$ & Vehicle & EPI-hNE4 (100 $\boldsymbol{\mu g} / \mathbf{m l})$ \\
\hline$\Delta I_{\text {sc }}\left(\mu \mathrm{A} / \mathrm{cm}^{2}\right)$ & $0.5 \pm 2.60$ & $-0.9 \pm 2.91$ & $0.2 \pm 2.15$ & $-0.3 \pm 2.52$ \\
\hline
\end{tabular}

Human nasal epithelial cells (HNEC) from control (non CF) and CF patients grown for 14 to 21 days on semi-permeable transwell filters were mounted in Ussing chamber and treated apically with either the hNE inhibitor EPI-hNE4 (final concentration $100 \mu \mathrm{g} / \mathrm{ml}$ ) or vehicle. $\Delta l_{\mathrm{sc}}$ represents the difference between final $I_{\mathrm{sc}}$ value at the end of experiment and basal $I_{\mathrm{sc}}$ value before apical addition of vehicle or EPI-hNE4 in control and CF HNEC. Results are expressed as means \pm SE ( $n=4-5$ individual filters for each condition). 


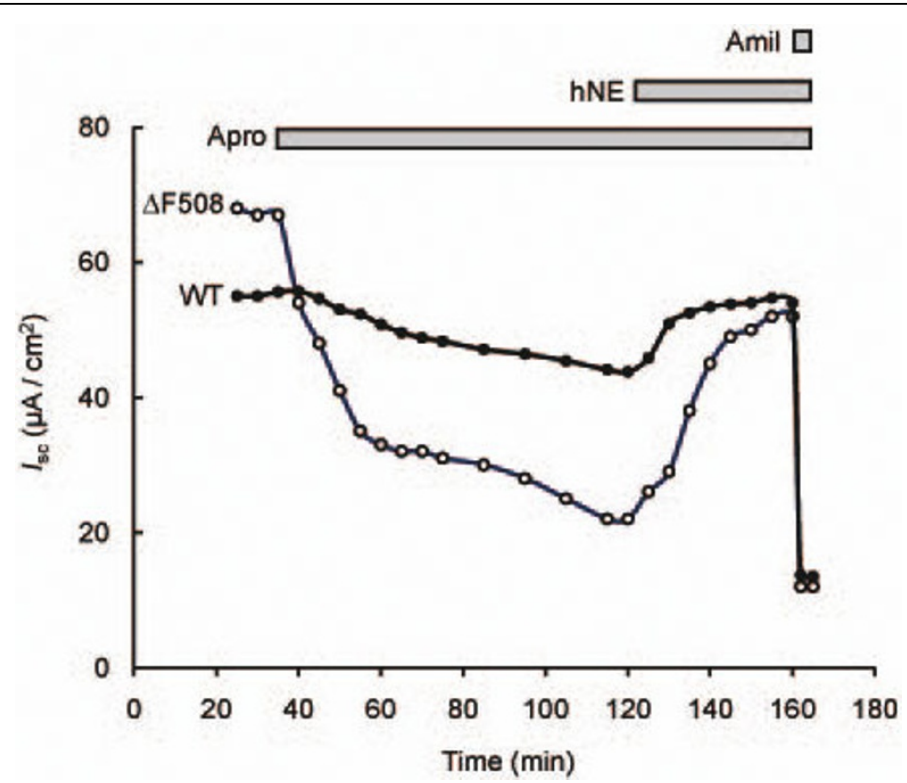

Figure 3 Representative traces of short-circuit current measurements showing the effect of hNE in control and CF HNEC incubated with aprotinin. HNEC from control (WT) and CF ( $\triangle F 508)$ patients grown on Snapwell filters were mounted in Ussing chamber and incubated apically with aprotinin (final concentration: $50 \mu \mathrm{g} / \mathrm{ml}$ ) for 90 min before hNE (final concentration: $33 \mu \mathrm{g} / \mathrm{ml}$ ) was added.

[10-14,17,27]. Membrane-bound Channel-Activating Proteases, which are co-expressed with $\mathrm{ENaC}$ in airway and alveolar epithelial cells $[15,20-22,24]$ but also in other epithelial cells transporting $\mathrm{Na}^{+}[12,14]$ have the ability to stimulate $\mathrm{ENaC}$ activity by increasing the channel opening probability, most likely through proteolytic cleavage of $\gamma$-ENaC subunit $[9,16]$. The effect of CAPs in lung epithelial cells is mimicked in vitro by trypsin, a serine protease which is normally not present in lung tissue $[15,21,27]$. Human neutrophil elastase is another serine protease present in CF airways at high concentrations due to the unrelenting infection and inflammation of the airways. Interestingly, Caldwell et al have recently reported that $\mathrm{ENaC}$ activity and transepithelial $\mathrm{Na}^{+}$transport could be increased by apical treatment with hNE in a human airway epithelial cell line [18]. The mechanism whereby hNE could activate $\mathrm{ENaC}$ function has been further analyzed in the xenopus laevis oocyte expression system. Harris et al have demonstrated that hNE could cleave the $\gamma$ subunit of $\mathrm{ENaC}$ at cell surface [28]. It can be therefore hypothesized that $\mathrm{ENaC}$ activation by hNE in vivo could in some way contribute to $\mathrm{ENaC}$ hyperactivity encountered in CF airways. However, as the models previously used to study the effect of hNE, either airway epithelial cell lines or xenopus laevis oocytes, may be far from the in vivo conditions, we found it useful to study the effect of hNE on $\mathrm{Na}^{+}$transport across both normal and CF human primary epithelial cells.
Our experiments showed that apical addition of increasing concentrations of hNE did not significantly modify transepithelial $\mathrm{Na}^{+}$transport as assessed by $\mathrm{I}_{\mathrm{sc}}$ measurements in normal or CF HNEC. These results are in sharp contrast with those obtained by Caldwell et al in a human airway cell line [18]. Yet, they are not really surprising as previous studies have demonstrated that apical treatment with the exogenous serine protease trypsin had no effect on sodium current in human nasal epithelial cells and in rat alveolar epithelial cells $[15,21]$, suggesting that in these primary cells, $\mathrm{ENaC}$ was fully activated by epithelium-derived serine proteases such as CAPs. It is important to note that the cell line used by Caldwell et al obviously did not show any endogenous CAP activity inasmuch as aprotinin (a non specific CAP inhibitor) incubation did not decrease $\mathrm{Na}^{+}$transport [18]. Therefore, we hypothesized that the lack of effect of hNE on $I_{\mathrm{sc}}$ in our experiments was due to the fact that $\mathrm{ENaC}$ channels, once inserted in the plasma membrane, were already maximally activated by CAPs so that hNE could not further increase $\mathrm{ENaC}$ activity. Consistent with this hypothesis, we demonstrated that hNE was able to activate $\mathrm{ENaC}$ and transepithelial $\mathrm{Na}^{+}$transport in both normal and CF HNEC, but only when endogenous serine proteases such as CAPs were inhibited by aprotinin. Of note, we observed that inhibition of $\mathrm{Na}^{+}$transport by aprotinin was significantly larger in CF HNEC than in control HNEC. This finding, in line with what was previously reported by Myerburg et al 

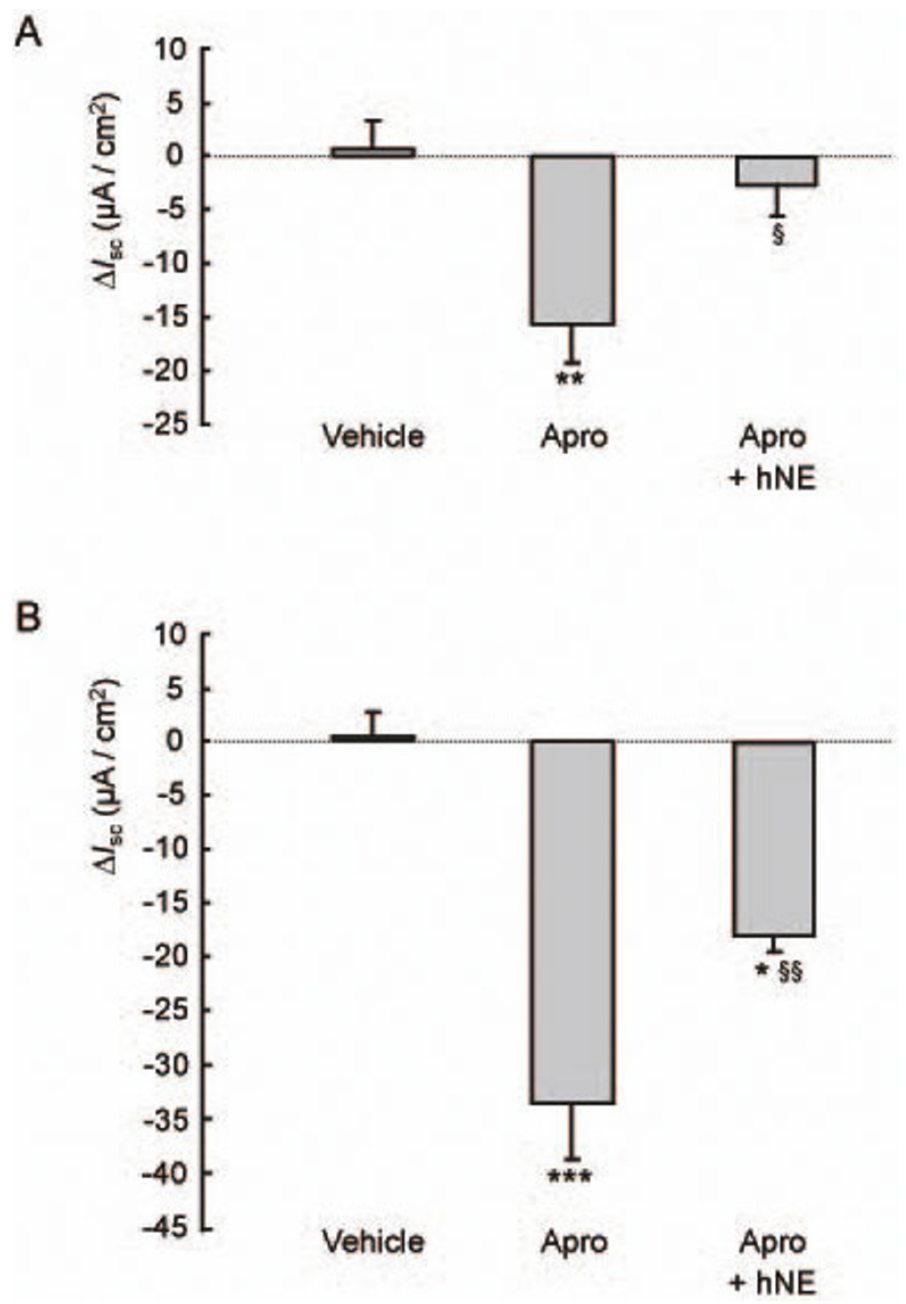

Figure 4 Effect of hNE on transepithelial $\mathrm{Na}^{+}$transport across control and CF HNEC treated with aprotinin. HNEC from control (panel A) and $C F(\triangle F 508)$ (panel B) patients grown on Snapwell filters and mounted in Ussing chamber were exposed apically to vehicle, aprotinin (50 $\mu \mathrm{g} / \mathrm{ml}$ ), or aprotinin (for $90 \mathrm{~min}$ ) followed by hNE $(33 \mu \mathrm{g} / \mathrm{ml})$. $\Delta I_{\mathrm{sc}}$ was calculated as the difference between the value of short-circuit current $\left(I_{\mathrm{sc}}\right)$ at the end of exposure to drug or vehicle and the baseline $I_{s c}$ at the moment of drug or vehicle addition. Results are expressed in $\mu \mathrm{A} / \mathrm{cm}^{2}$ and represent means $\pm \mathrm{SE}$ of four to ten filters for each condition. ${ }^{* *},{ }^{* * *}$ : significantly different from vehicle $(\mathrm{P}<0.01$ and $\mathrm{P}<0.001$, respectively); $\S$, $\S \S$ s significantly different from aprotinin alone $(P<0.05$ and $P<0.01$, respectively).

[29], suggests that the activity of epithelial serine proteases, most likely CAPs, is increased in CF airways. We also noticed that, although hNE-stimulated $I_{\mathrm{sc}}$ after aprotinin tended to be larger in CF than in control HNEC, hNE treatment failed to restore $\mathrm{Na}^{+}$transport at baseline value in CF cells, unlike in control cells. This suggests that in CF HNEC, hNE cannot fully substitute for aprotinin-sensitive epithelial serine proteases.

Another objective of the study was to test the effect of EPI-hNE4, a specific and potent inhibitor of hNE derived from the second Kunitz-type domain of inter- $\alpha$ inhibitor protein $[22,28]$, on $\mathrm{ENaC}$ and transepithelial $\mathrm{Na}^{+}$across primary HNEC. Our data show that under baseline conditions, EPI-hNE4 by itself did not modify $I_{\mathrm{sc}}$ in normal or CF HNEC. This indicates that EPI-
hNE4 does not inhibit CAP activity in these cells, which is not really surprising considering the fact that this compound is highly selective for hNE. However, EPIhNE4 completely blocked the increase in $I_{\mathrm{sc}}$ induced by hNE in cells first incubated with aprotinin.

Taken together, our results indicate that hNE is a potent activator of $\mathrm{ENaC}$ in primary nasal epithelial cells, but the physiological importance of this effect is questionable, inasmuch as $\mathrm{ENaC}$ seems to be constitutively maximally activated by epithelium-derived serine proteases such as CAPs, at least under physiological conditions. As far as we could see, EPI-hNE4 potently inhibited hNE, but failed to inhibit endogenous epithelium-derived CAPs, at least at the concentration used in this study. Yet, the present study does not rule out the 
Table 3 Comparison of the effects of aprotinin and hNE on $I_{\mathrm{sc}}$ in control and CF HNEC

\begin{tabular}{ccc}
\hline & \multicolumn{2}{c}{ Change in $\boldsymbol{I}_{\mathbf{s c}} \boldsymbol{\mu A} / \mathbf{c m}^{2}$ (\% baseline $\left.\boldsymbol{I}_{\mathbf{s c}}\right)$} \\
\cline { 2 - 3 } & Aprotinin & hNE \\
\hline Control HNEC & $-15.7 \pm 3.56$ & $9.5 \pm 1.80$ \\
& $(-27.6 \pm 3.47 \%)$ & $(18.5 \pm 3.33 \%)$ \\
\hline CF HNEC & $-33.9 \pm 5.20 *$ & $20.4 \pm 4.47$ \\
& $(-54 \pm 8.18 \%)^{* *}$ & $(32.1 \pm 6.7 \%)$ \\
\hline
\end{tabular}

Human nasal epithelial cells (HNEC) from control and CF patients were grown for 14 to 21 days on semi-permeable transwell filters until transepithelial resistance developed. Transwell filters were mounted in Ussing chamber for $I_{\mathrm{sc}}$ measurements, and exposed apically to vehicle, aprotinin $(50 \mu \mathrm{gg} / \mathrm{ml})$, or aprotinin (for $90 \mathrm{~min}$ ) followed by hNE $(33 \mathrm{\mu g} / \mathrm{ml})$. The change in $I_{s c}$ induced by aprotinin represents the difference between the value of $I_{s c}$ at the end of aprotinin exposure and baseline $I_{s c}$ at the moment of aprotinin addition. The change in $I_{s c}$ induced by hNE represents the difference between peak $I_{s c}$ value following $\mathrm{hNE}$ addition and $I_{s c}$ value at the moment of hNE addition. Results are expressed in $\mu \mathrm{A} / \mathrm{cm}^{2}$ and in percentage of baseline $I_{s c}$ and represent means \pm SE of 4 to 10 filters for each condition. ${ }^{*}{ }^{* *}$ : significantly different from corresponding value in control HNEC group $(P<0.05$ and $P<0.01)$.

possibility that, under pathological conditions such as airway inflammation encountered during $\mathrm{CF}$, activation of ENaC by excess hNE released by neutrophils could be important. Interestingly, it has been reported that prostasin (CAP1) expression was markedly decreased in renal epithelial cells (M1 cell line) treated with TGF $\beta-1$, a prototypic inflammatory cytokine [30]. Therefore, one can speculate that the expression and activity of endogenous CAPs might as well be reduced during airway inflammation, and that the stimulatory effect of hNE on $\mathrm{ENaC}$ could be unmasked. On this condition, the use of EPI-hNE4 could be of interest to reduce $\mathrm{ENaC}$ hyperactivity in CF airways. In order to elucidate the role of hNE on transepithelial $\mathrm{Na}^{+}$transport under inflammatory conditions, we intend to expose HNEC to prototypic inflammatory cytokines such as TGF $\beta-1$ or IL1- $\beta$, which are known to decrease $\mathrm{ENaC}$ activity in these cells $[25,30,31]$, and to study the effect of hNE.

\section{Acknowledgements}

This study was funded by Inserm and Debiopharm. EPI-hNE4 was developed by Dyax Corp., Cambridge, MA.

\footnotetext{
Author details

'INSERM, U 955, Créteil, F-94000, France. ²Université Paris Est, Créteil F-94000, France. ${ }^{3}$ AP-HP, Hôpital Intercommunal et Groupe Hospitalier Henri-MondorAlbert-Chenevier, Service d'Oto-Rhino-Laryngologie et de Chirurgie CervicoFaciale, Créteil F-94000, France. ${ }^{4}$ INSERM, U 773, CRB3, Paris F-75018, France. ${ }^{5}$ Université Denis Diderot-Paris 7, F-75013 Paris, France. ${ }^{6}$ AP-HP, Hôpital Bichat-Claude Bernard, Service de Physiologie, Paris, F-75018, France. ${ }^{7}$ Debiopharm SA, Lausanne CH-1005, Switzerland. ${ }^{8}$ INSERM, U 933, Paris F75012, France. ${ }^{9}$ Université Pierre et Marie Curie Paris 6 and AP-HP, Hôpital Armand Trousseau, F-75012 Paris, France. ${ }^{10}$ Equipe d'Accueil EA 2363, Université Paris 13, Bobigny F-93009, France. "11 AP-HP, Hôpital Avicenne, Service de Physiologie, Bobigny F-93009, France.
}

\section{Authors' contributions}

VPE carried out primary cultures from human nasal epithelial cells, shortcircuit measurements, analysis and interpretation of data and participated to draft the manuscript.
CC participated in the study design and coordination.

GV participated in the study design and provided EPI-hNE4.

$A C$ has been involved in revising this study before its submission.

EE has been involved in revising this study before its submission

$\mathrm{CP}$ conceived and designed the study and participated in its coordination,

statistical analysis and helped to draft the manuscript.

All authors read and approved the final manuscript.

\section{Competing interests}

The authors declare that they have no competing interests.

Received: 15 March 2010 Accepted: 8 October 2010

Published: 8 October 2010

\section{References}

1. Boucher RC: New concepts of the pathogenesis of cystic fibrosis lung disease. Eur Respir J 2004, 23:146-158.

2. Canessa C, Horisberger J-D, Rossier BC: Epithelial sodium channel related to proteins involved in neurodegeneration. Nature (Lond) 1993, 361:467-470

3. Canessa C, Schild L, Buell G, Thorens B, Gautschi I, Horisberger J-D, Rossier BC: Amiloride-sensitive epithelial $\mathrm{Na}^{+}$channel is made of three homologous subunits. Nature (Lond) 1994, 367:463-467.

4. Mall M, Bleich M, Greger R, Schreiber R, Kunzelmann K: The amiloride inhibitable $\mathrm{Na}^{+}$conductance is reduced by CFTR in normal but not in cystic fibrosis airways. J Clin Invest 1998, 102:15-21.

5. König J, Schreiber R, Voelcker T, Mall M, Kunzelmann K: The cystic fibrosis transmembrane conductance regulator (CFTR) inhibits ENaC through an increase in the intracellular $\mathrm{Cl}^{-}$concentration. EMBO reports 2001, 21:1047-1051.

6. Mall M, Grubb BR, Harkema JR, O'neal WK, Boucher RC: Increased airway epithelial $\mathrm{Na}+$ absorption produces cystic-fibrosis-like lung disease in mice. Nat Med 2004, 10:487-93.

7. Matthay MA, Folkesson $H G$, Clerici C: Lung epithelial fluid transport and the resolution of pulmonary edema. Physiol Rev 2002, 82:569-600.

8. Planès C, Caughey GH: Regulation of the Epithelial Sodium Channel by peptidases. Curr Top Dev Biol 2007, 78:23-46.

9. Rossier BC, Stutts MJ: Activation of the epithelial sodium channel (ENaC) by serine proteases. Annu Rev Physiol 2009, 71:361-379.

10. Vallet V, Chraibi A, Gaeggeler H-P, Horisberger J-D, Rossier BC: An epithelial serine protease activates the amiloride-sensitive sodium channel. Nature 1997, 389:607-610

11. Vallet V, Pfister C, Loffing J, Rossier BC: Cell-surface expression of the channel activating protease XCAP-1 is required for activation of ENaC in the Xenopus oocyte. J Am Soc Nephrol 2002, 13(3):588-94.

12. Vuagniaux $G$, Vallet $V$, Fowler Jaeger $N$, Pfister $C$, Bens M, Farman N, Courtois-Coutry N, Vandewalle A, Rossier BC, Hummler E: Activation of the amiloride-sensitive epithelial sodium channel by the serine protease mCAP1 expressed in a mouse cortical collecting duct cell line. J Am Soc Nephrol 2000, 11:828-834.

13. Adachi M, Kitamura K, Miyoshi T, Narikiyo T, Iwashita K, Shiraishi N, Nonoguchi $H$, Tomita K: Activation of epithelial sodium channels by prostasin in Xenopus oocytes. J Am Soc Nephrol 2001, 2(6):1114-21.

14. Vuagniaux G, Vallet V, Fowler Jaeger N, Hummler E, Rossier BC: Synergistic activation of $\mathrm{ENaC}$ by three membrane-bound channel-activating serine proteases (mCAP1, mCAP2, and mCAP3) and serum- and glucoseregulated kinase (Sgk1) in Xenopus oocytes. J Gen Physiol 2002, 120:191-201.

15. Donaldson SH, Hirsh A, Li DC, Holloway G, Chao J, Boucher RC, Gabriel SE: Regulation of the epithelial sodium channel by serine proteases in human airways. J Biol Chem 2002, 277:8338-8345.

16. Guipponi M, Vuagniaux G, Wattenhofer M, Shibuya K, Vazquez M, Dougherty L, Scamuffa N, Guida E, Okui M, Rossier C, Hancock M, Buchet K, Reymond A, Hummler E, Marzella PL, Kudoh J, Shimizu N, Scott HS, Antonarakis SE, Rossier BC: The transmembrane serine protease (TMPRSS3) mutated in deafness DFNB8/10 activates the epithelial sodium channel (ENaC) in vitro. Hum Mol Genet 2002, 11(23):2829-36.

17. Okumura $Y$, Nishikawa M, Cui $P$, Shiota M, Nakamura $Y$, Adachi M, Kitamura K, Tomita K, Kido $\mathrm{H}$ : Cloning and characterization of a transmembrane-type serine protease from rat kidney, a new sodium channel activator. J Biol Chem 2003, 384(10-11):1483-95. 
18. Bruns JB, Carattino MD, Sheng S, Maarouf AB, Weisz OA, Pilewski JM, Hughey RP, Kleyman TR: Epithelial $\mathrm{Na}^{+}$channels are fully activated by furin- and prostasin-dependent release of an inhibitory peptide from the gamma-subunit. J Biol Chem 2007, 282(9):6153-60.

19. Chraïbi A, Vallet V, Firsov D, Hess SK, Horisberger JD: Protease modulation of the activity of the epithelial sodium channel expressed in Xenopus oocytes. J Gen Physiol 1998, 111(1):127-38.

20. Caldwell RA, Boucher RC, Stutts MJ: Neutrophil elastase activates nearsilent epithelial $\mathrm{Na}^{+}$channels and increases airway epithelial $\mathrm{Na}^{+}$ transport. Am J Physiol Lung Cell Mol Physiol 2005, 288:L813-L819.

21. Liu L, Hering-Smith KS, Schiro FR, Hamm LL: Serine protease activity in m1 cortical collecting duct cells. Hypertension 2002, 39(4):860-4.

22. Verghese GM, Tong ZY, Bhagwandin V, Caughey GH: Mouse prostasin gene structure, promoter analysis, and restricted expression in lung and kidney. Am J Respir Cell Mol Biol 2004, 30(4):519-29.

23. Planès $C$, Leyvraz $C$, Uchida $T$, Angelova $M A$, Vuagniaux $G$, Hummler $E$, Matthay MA, Clerici C, Rossier BC: In vitro and in vivo regulation of transepithelial lung alveolar sodium transport by serine proteases. Am J Physiol Lung Cell Mol Physiol 2005, 288:L1099-L1109.

24. Planès $\mathrm{C}$, Randrianarison NH, Charles RP, Frateschi $\mathrm{S}$, Cluzeaud F, Vuagniaux G, Soler P, Clerici C, Rossier BC, Hummler E: ENaC-mediated alveolar fluid clearance and lung fluid balance depend on the channelactivating protease 1. EMBO Mol Med 2010, 2(1):26-37.

25. Bridges RJ, Newton BB, Pilewski JM, Devor DC, Poll CT, Hall RL: $\mathrm{Na}^{+}$ transport in normal and CF human bronchial epithelial cells is inhibited by BAY 39-9437. Am J Physiol Lung Cell Mol Physiol 2001, 281:L16-L23.

26. Tong Z, Illek B, Bhagwandin VJ, Verghese GM, Caughey GH: Prostasin, a membrane-anchored serine peptidase, regulates sodium currents in JME/CF15 cells, a cystic fibrosis airway epithelial cell line. Am J Physiol Lung Cell Mol Physiol 2004, 287(5):L928-35.

27. Prulière-Escabasse V, Fanen $P$, Dazy AC, Lechapt-Zalcman E, Rideau $D$, Edelman A, Escudier E, Coste A: TGF- $\beta 1$ downregulates CFTR expression and function in nasal polyps of non-CF patients. Am J Physiol Lung Cell Mol Physiol 2005, 288:L77-L83.

28. Mall M, Harkema JR, Trojanek JB, Treis D, Livraghi A, Schubert S, Zhou Z, Kreda SM, Tilley SL, Hudson EJ, O'Neal W, Boucher RC: Development of chronic bronchitis and emphysema in beta-epithelial $\mathrm{Na}+$ channel overexpressing mice. Am J Respir Crit Care Med 2008, 177(7):730-42

29. Swystun V, Chen L, Factor P, Siroky B, Bell PD, Matalon S: Apical trypsin increases ion transport and resistance by a phospholipase C-dependent rise of $\mathrm{Ca}^{2+}$. Am J Physiol Lung Cell Mol Physiol 2005, 288:L820-30.

30. Harris M, Firsov D, Vuagniaux G, Stutts MJ, Rossier BC: A novel neutrophil elastase inhibitor prevents elastase activation and surface cleavage of the epithelial sodium channel expressed in Xenopus laevis oocytes. J Biol Chem 2007, 282(1):58-64.

31. Myerburg MM, Butterworth MB, McKenna EE, Peters KW, Frizzell RA, Kleyman TR, Pilewski JM: Airway surface liquid volume regulates $\mathrm{ENaC}$ by altering the serine protease-protease inhibitor balance. A mechanism for sodium hyperaborption in cystic fibrosis. J Biol Chem 2006, 281(38):27942-27949.

32. Tuyen DG, Kitamura K, Adachi M, Miyoshi T, Wakida N, Nagano J, Nonoguchi $\mathrm{H}$, Tomita $\mathrm{K}$ : Inhibition of prostasin expression by TGF- $\beta 1$ in renal epithelial cells. Kidney Int 2005, 67:193-200.

33. Barmeyer C, Amasheh S, Tavalali S, Mankertz J, Zeitz M, Fromm M, Schulzke JD: IL-1 beta and TNFalpha regulate sodium absorption in rat distal colon. Biochem Biophys Res Com 2004, 317(2):500-7.

doi:10.1186/1465-9921-11-141

Cite this article as: Prulière-Escabasse et al: Effect of neutrophil elastase and its inhibitor EPI-hNE4 on transepithelial sodium transport across normal and cystic fibrosis human nasal epithelial cells. Respiratory Research 2010 11:141.

\section{Submit your next manuscript to BioMed Central and take full advantage of:}

- Convenient online submission

- Thorough peer review

- No space constraints or color figure charges

- Immediate publication on acceptance

- Inclusion in PubMed, CAS, Scopus and Google Scholar

- Research which is freely available for redistribution

Submit your manuscript at www.biomedcentral.com/submit
Biomed Central 